
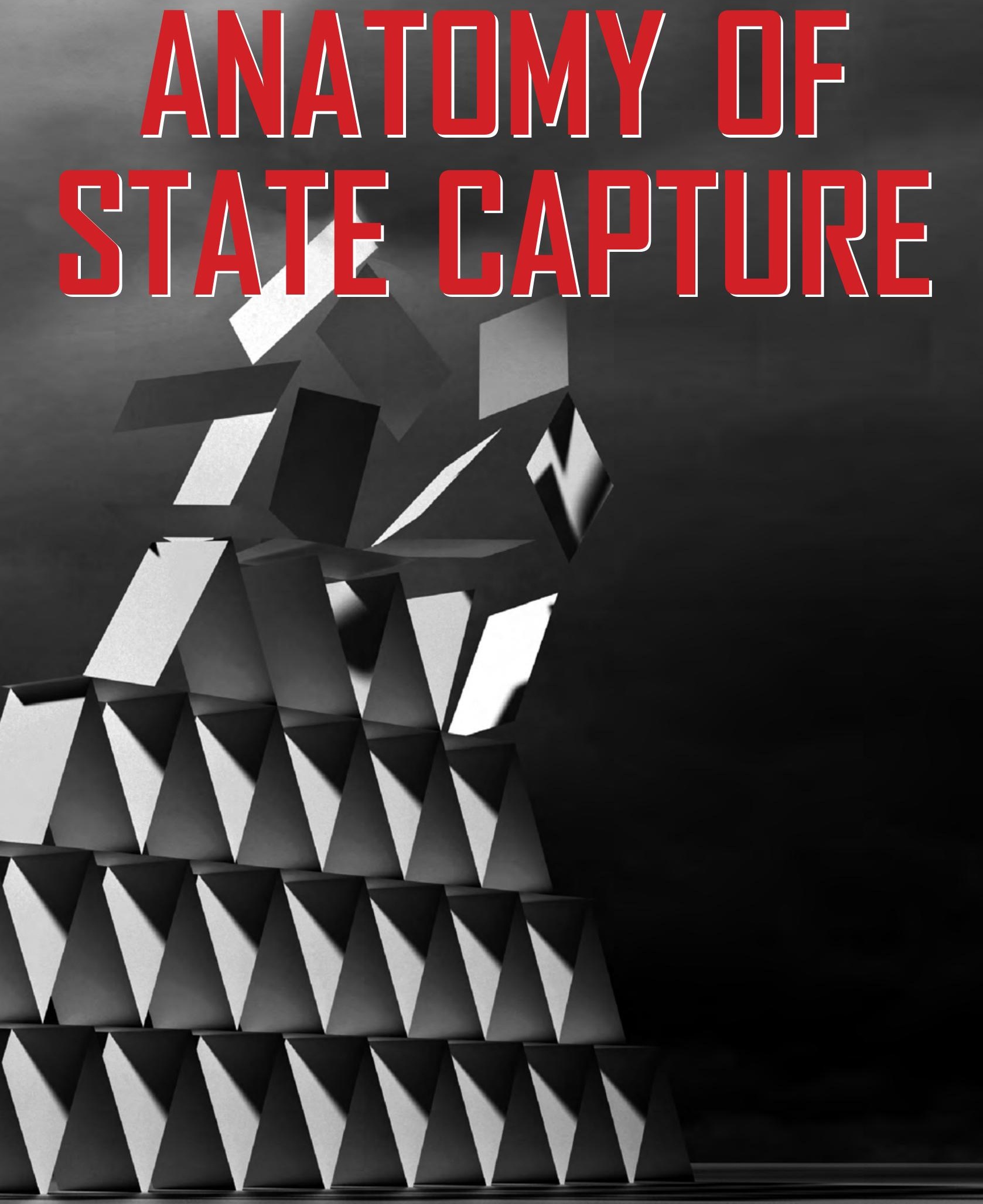

Nina Callaghan, Rabyn Foley and Mark Swilling (EDITuRS) 


\section{STATE CAPTURE: WHY NOBODY DID ANYTHING TO STOP IT}

"State capture" has become a euphemism for rampant looting of state resources, but it is a far more sophisticated enterprise than that. State capture is a form of organised political corruption in which private interests, typically business people, are able to influence the decisions of state organs in order to serve their profit motives.

Writing for International Finance \& Development, a magazine of the International Monetary Fund (IMF), Joel Hellman and Daniel Kaufman (2001) said: "We define state capture as the efforts of firms to shape the laws, policies, and regulations of the state to their own advantage by providing illicit private gains to public officials."

The term was virtually absent from regular conversation until the former Public Protector, Advocate Thuli Madonsela, released a report in November 2016 titled State of Capture. The report was the outcome of an investigation into complaints of alleged improper and unethical conduct by then President Jacob Zuma and other government and state officials,

relating to alleged improper relationships and involvement of the Gupta family in the removal and appointment of ministers and directors of State Owned Entities (SOEs) resulting in improper and possibly corrupt award of state contracts and benefits to the Gupta family's businesses. (Public Protector, 2016, p. 27)

The report detailed what appeared to be a crude and de facto takeover of various state institutions, in particular SOEs, to facilitate the siphoning of large amounts of money through irregularly awarded contracts, an endeavour that was pursued with incredible zeal and on an industrial scale. In the recommendations contained in the State of Capture (2016) report, Advocate Madonsela asked the President to appoint a Judicial Commission of Inquiry whose powers would be no less than those of the Public Protector in order to perform a deeper investigation into the matters unearthed in her voluminous report. Deputy Chief Justice Raymond Zondo was appointed to head up such a commission, whose work was still continuing at the time of writing in 2020 . 
The State of Capture report is over 400 pages long, and details some of the most egregious acts of impropriety imaginable. Many of these were, in any event, widely reported in the media. For instance, the Mail \& Guardian newspaper and investigative journalism outfit, amaBhungane, had been publishing stories about alleged corruption at Transnet many years before the Public Protector's investigation even began.

If the State of Capture (2016) report gave an account of how the initiation and awarding of contracts in state-owned companies was rigged to the liking of the Guptas, it was the explosive revelations by the then Deputy Minister of Finance, Mcebisi Jonas, that brought the point home more than at any other time. On 16 March 2016, he released a televised public statement that Ajay Gupta had offered him an immediate R600 000 cash bribe and R600m in total if he took up the position of Finance Minister and subsequently do their bidding (SABC Digital News, 2016). This rightfully shocked and outraged the country in that it was a first-hand public account of the extent to which the Guptas were seemingly in control of affairs of the government.

As South Africans have come to know through the State of Capture report and various witness submissions at the Judicial Commission of Inquiry on State Capture, various powerful interests exerted significant influence on state organs and officials and was spoken about in political and government circles but was never reported publicly. It was seemingly an open secret.

Why did no one speak out? How was this phenomenon allowed to take root since it did not occur suddenly?

It is a critical question whose answers lie in a complex set of circumstances that require nuanced deconstruction in order for them to make sense. While the Judicial Commission of Inquiry on State Capture (the Zondo Commission) will detail a lot of what happened, not just within the Gupta axis but also Bosasa, South African Airways (SAA) and other institutions, it is unlikely to answer the question that is central to this chapter.

In my opinion there are six reasons why very few were able to raise a noticeable and consistent alarm, let alone mount a serious challenge to state capture.

\subsection{THE ANC'S INTERNAL CULTURE AND ORGANISATIONAL CHARACTER}

The South African Constitution conceives a State that, in its conduct, is non-partisan and is there to serve the interests of all South Africans. It directs the South African parliament to enact laws that create a fair, transparent system of government. 
However, that same Constitution does not set clear parameters on the level of influence political appointees may have on the administration of government departments, agencies and SOEs. For instance, the ANC has a Deployment Committee chaired by the Deputy President of the party (ANC, 2021). It deliberates and decides on key party and state appointments which includes key roles in parliament. While such a committee makes sense in the case of Parliament, it is difficult to see how it can make the same appointments in the civil service given that all civil service posts are supposed to be advertised and follow a fair process of selection without undermining the legal requirement to give all applicants a fair chance. Provincial, regional and local structures of the party engage in similar actions at the congruent level, raising similar questions throughout.

In my view, the concept and practice of limitless "deployment" of party cadres to key positions of state introduces a level of party influence on the affairs of state that is antithetical to what is envisaged in the Constitution. State organs are supposed to be non-partisan.

During the first term of democratic government (1994-1999), there was a compelling rationale for deployment of people from outside existing state structures because the ANC was anxious to not retain apartheid-era civil servants in key positions who may have been an obstacle to its policy agenda (Maphunye, 2002). However, as the organisational culture began to deteriorate, and corruption in party structures took root, it became inevitable that membership of the party offered opportunities for lucrative "deployments" in government, and with them the possibility to influence state decisions in favour of the party and private interests that supported their election in the party structures.

Making for fascinating reading, in this context, are the political and organisational reports by the President and Secretary-General of the ANC to the 51st National Conference in Stellenbosch and the now fateful 52nd National Conference in Polokwane. On both occasions Thabo Mbeki and Kgalema Motlanthe were President and Secretary-General respectively, and their reports demonstrate the extent to which the party degenerated, laying the seeds for state capture - a project that should have been predictable.

In his Organisational Report to the 51st National Conference in Stellenbosch during which time he was still ANC Secretary-General, Kgalema Motlanthe stated:

We found that issues dividing some of the leadership of some of our provinces are not of a political nature, but have mainly revolved around access to resources, positioning themselves or others to access resources, 
dispensing patronage and in the process using organisational structures to further these goals. (Motlanthe, 2002)

Over time this resulted in a crude, transactional approach to the appointment of senior state officials. In the period leading up to Elective Conferences at different levels, those who wished to be appointed in government would begin by supporting a particular faction within the party, and when that faction became successful, it would facilitate those appointments.

In return, the said officials would facilitate access to government contracts, a series of "gratifications" that are regarded as criminal by the Prevention and Combating of Corrupt Activities Act of 2004 (PRECCA) (Republic of South Africa, 2005). It will be difficult to find any instance where someone was successfully prosecuted in terms of this law, even though it was established to combat just this sort of transaction.

There were suggestions as to the depth of the problem in an article in the Financial Mail, authored by Carol Paton (2007) in which the Kimberley Municipality was used as an example. The article suggests that political seniors in the ANC 'deployed' cadres to businesses, and in this way decided the tender process.

Soon a handful of ANC-aligned businesspeople were winning contract after contract - whether in security, transport or construction. A minor revolt in the party ended in defeat, when a group of rebels from the Kimberley region tabled a resolution at the party's 2001 conference, arguing that BEE should be broad-based and not favour just a selected few. (Paton, 2007)

In the article, Motlanthe is quoted as saying

This rot is across the board. It's not confined to any level or any area of the country. Almost every project is conceived because it offers opportunities for certain people to make money. A great deal of the ANC's problems are occasioned by this. There are people who want to take it over so they can arrange for the appointment of those who will allow them possibilities for future accumulation. (Paton, 2007)

In his final political report to the 52nd National Conference of the ANC, held in Polokwane in December 2007, former President Mbeki said:

Many such members view positions in government as a source of material riches for themselves. Thus resources, prestige and authority of government positions become the driving force in competition for leadership positions in the ANC. Government positions also go hand-in-hand with the possibility to issue contracts to commercial companies. Some of these companies identify ANC members that they can promote in ANC structures and into government, so that they can get contracts by hook or by crook. (Mbeki, 2007) 
Mbeki and Motlanthe held the two most powerful positions in the party, President and Secretary-General, for a decade. Their insights into the culture of corruption in the party, and how party structures fell into the hands of rogue elements who were interested in self-accumulation are not guess work, but the result of personal experience as they watched the party they led deteriorate.

The practice of private interests colluding with ANC leaders in order to direct state organs in their favour is not new. It simply became bigger, and in the case of the Gupta family, systematic and on an industrial scale.

\subsection{THE DESTRUCTION OF THE SCORPIONS AND THE BIRTH OF SOPHISTICATED DISINFORMATION}

The second reason state capture later accelerated at an alarming rate is that the only crime-fighting force that had any chance of pursuing complex corruption cases, the Directorate of Special Operations (DSO) otherwise known as the Scorpions, was disbanded because of an ANC National Conference resolution in December 2007. This followed several high profile prosecutions, the most prominent of which was the conviction of a Durban businessman, Schabir Shaik, on corruption charges in 2005 (High Court of South Africa: Natal Provincial Division, 2005).

The charges were that, over several years, he had paid a series of gratifications to Jacob Zuma in exchange for the latter to use his political office (he was KZN's Member of the Executive Council [MEC] for Economic Affairs at the time) in order to advance his business interests. Indeed, according to evidence led at the trial, which the court found to be credible, Shaik would wheel Zuma out whenever he needed to convince potential business partners and investors that he had the backing of powerful politicians.

In his judgment, Judge Hilary Squires said:

It would be flying in the face of common sense and ordinary human nature to think that he (Shaik) did not realise the advantages to him of continuing to enjoy Zuma's goodwill to an even greater extent than before 1997; and even if nothing was ever said between them to establish the mutually beneficial symbiosis that the evidence shows existed, the circumstances of the commencement and the sustained continuation thereafter of these payments, can only have generated a sense of obligation in the recipient. If Zuma could not repay money, how else could he do so than by providing the help of his name and political office as and when it was asked, particularly in the field of government contracted work, which is what Shaik was hoping to benefit from. (High Court of South Africa: Natal Provincial Division, 2005, p. 52) 
And later in the judgment, he said:

It seems an inescapable conclusion that he embarked on this never ending series of payments when he realised the extent of Zuma's indebtedness . .. and the extent to which Zuma was living beyond his income; and he also realised the possible advantages to his business interests of providing the means to retain Zuma's goodwill by helping him to support a lifestyle beyond what he could afford on his Minister's remuneration. (High Court of South Africa: Natal Provincial Division, 2005, p. 53)

Shaik's conviction in 2005 led to the dismissal of Jacob Zuma as Deputy President that same year, an event that kicked off a wave of political machinations against such prosecutions, with the Scorpions being the main target. The narrative that won the day was that these prosecutions were designed to prevent Jacob Zuma from ascending to the role of President, and that he was in any event 'innocent until proven guilty', as the common refrain went.

Soon thereafter, Zuma was charged with rape, a case in which he was found not guilty. The feeling within the party that he was being persecuted, accelerated at an alarming rate. The narrative morphed from targeting the Scorpions alone to the National Prosecuting Authority (NPA) as well, to which the Scorpions belonged. This was not just a conspiracy peddled within party structures and dinner or barroom conversations. It permeated deep into the news media.

While the "State" is composed of three arms, namely: parliament, the judiciary and the government Executive as led by the President, our democratic architecture has a fourth, albeit informal arm. This is the news media.

Not only do all arms of the state rely heavily on the news media to inform citizens, the latter also rely on it to shine a light on impropriety so that citizens may do something about it. This role is entirely dependent on a relationship of trust between the public and news organisations. Journalism's sacred role involves gatekeeping, essentially the careful checking and verification of information before providing it to the public as news.

While these days most will remember the role of the now-defunct British "dirty PR" firm, Bell Pottinger, in creating false narratives and distributing false information at the height of the Gupta-led state capture project, the practice was not new. It went as far back as 2005, the year Jacob Zuma was fired as Deputy President by Thabo Mbeki and was facing indictment for the same corruption charges Schabir Shaik had been convicted of in the Durban High Court that same year.

The detailed background is to be found in a 2005 article published in the Mail \& Guardian (Sole \& Dawes, 2005). In short, an elaborate attempt to provide "proof" of 
a conspiracy to discredit and compromise Zuma was made, seemingly by elements connected to the then National Intelligence Agency (NIA), some of whom were known to be loyal to Zuma. The so-called proof was in some allegedly intercepted email communication between various ANC politicians, such as Ronnie Kasrils, Phumzile Mlambo-Ngcuka, Mzi Khumalo, the then National Director of Public Prosecution, Bulelani Ngcuka and others. Ngcuka is the husband to Mlambo-Ngcuka who had been appointed Deputy President following Zuma's dismissal from the government (Sole \& Dawes, 2005).

The emails were clearly fake as the time lapse between responses was sometimes a matter of seconds, and the language used was hardly that of people involved in a clandestine conspiracy. Everything was said in as crude a manner as possible, such as tribalistic references. For instance, Zuma was ostensibly referred to as "the Zuluboy", something his supporters were to later take up as a mantle while protesting against his reported persecution. The Office of the Inspector General of Intelligence (OIGI, 2006) would later confirm the emails as fake. It was an astonishing development that took many years to debunk but formed a substantial basis for a narrative of persecution that Zuma pursues to this day despite any and all proof that he has a case to answer for.

The Scorpions were said to be the spear of Zuma's victimisation. The narrative also had the support of other, questionable initiatives by the NIA, such as Project Avani (OIGI, 2006). This project was supposed to be a 360-degree scan of the political horizon but somehow ended up targeting figures and institutions that were perceived to be either close to then President Mbeki or acting on Mbeki's behalf against Zuma.

At this point it became clear that various parts of the law enforcement and security apparatus were either being used to fight the ANC's internal battles or were caught up in those battles. This assertion was confirmed with the revelation in April 2009 by Acting National Director of Public Prosecutions (NDPP), Advocate Mokotedi Mpshe, that former deputy NDPP and head of the Scorpions, Advocate Leonard McCarthy, had sought the advice of his former boss, Bulelani Ngcuka about the 'best' time at which to charge Zuma with corruption. It was alarming as Ngcuka was no longer NDPP and McCarthy had no business consulting him about an ongoing case, especially since the considerations were political.

It was not surprising, therefore, that in December 2007 the ANC's 52nd National Conference took a decision to disband the Scorpions and replace them with a new unit. Early 2008, then Minister of Safety and Security, Charles Nqakula had announced in parliament that the Scorpions would be disbanded (Roelf, 2008) - by October 2008 it was done. 
I believe that this is the inflection point at which it became possible for state capture to happen on the industrial scale we were to witness in the coming years, for two reasons. First, the politics surrounding the law enforcement and security agencies meant that they began to be discredited and lose the trust of citizens. Secondly, the news media began to be caught up in ANC politics, too. Instead of analysing and surfacing sharply the meaning of what was going on, the reporting merely focused on what was going on. This robbed South Africans of the ability to correctly perceive the political events and assist them in forming useful opinions on the political choices they would subsequently make.

This is not to say that no one in the news media attempted to do this, but the kind of reporting that quoted unnamed ANC factionalists ad nauseum, making assertions that they did not back up with any facts, was not helpful at all. The "so what" was lost, reduced to the fight between "Zumaites" and "Mbekites", with very little attention paid to what this portended for the future of the rule of law.

I also believe that it was in this climate that ANC members with a solid moral fibre no longer cared when Mbeki delivered his final political report at the ANC's Polokwane Conference in December 2007. In it he warned:

\begin{abstract}
All of us are aware of the poisonous phenomenon foreign to our movement, which many of us have characterised as the ownership of some members by other members. These are people who, while holding ANC membership cards, do not belong to the ANC but belong to those who paid their subscriptions. This includes unqualified people who get appointed to such positions as Municipal Managers, place men and women who serve as the pliable tools of their political masters, and who are used to advance the commercial and political interests of their handlers and patrons. (Mbeki, 2007)
\end{abstract}

The phenomenon above fits the textbook definition of "state capture", with the only difference being that during the Zuma Presidency, this phenomenon accelerated to an alarming speed, and took on key national institutions.

In fact, another event that does not get mentioned in the same vein as state capture was, in fact, the beginning of the end for the South African Police Service (SAPS), which was headed by the late Mr Jackie Selebi as National Police Commissioner. On 10 September 2007, the NPA issued a warrant for his arrest on corruption charges. The story of what happened next is too long to repeat here, except to say that the National Director of Public Prosecutions at the time, Advocate Vusi Pikoli was suspended as a result.

In his memoir, Pikoli describes what led to Selebi being investigated, detailing how police officers were moonlighting for a private security firm, Palto, where they 
effectively became "Selebi's own dirty tricks squad of vigilante freelancers who were using the SAPS and commissioner as cover" (Pikoli \& Wiener, 2013, p. 236). He continues:

Most alarming was a claim by Stemmet about how he had tipped Selebi off about Agliotti's involvement in a R105 million drug bust in Kya Sands in 2002, but the commissioner chose to ignore the warning. Instead, Selebi's photograph at the drug bust appeared on the front page of national newspapers. It would later emerge in court that Agliotti was, in fact, paid an informant's fee for the bust rather than having been arrested. (Pikoli \& Wiener, 2013, p. 236)

Glen Agliotti was an underworld criminal who later entered into a plea bargain and testified against Selebi at his corruption trial. While Selebi was to later be convicted and sentenced to 15 years imprisonment for corruption (Basson, 2010), this incident shows once again how it was possible for criminal elements to commandeer state officials and institutions in cahoots with those entrusted with the task of overseeing them, for their own criminal ends.

For his part, Pikoli was suspended on 18 September 2007 pending an inquiry into his fitness for office. Despite being vindicated by the subsequent Ginwala Inquiry (2008), Pikoli was nonetheless removed from his position by Mbeki's temporary successor, Kgalema Motlanthe. The government later settled its legal dispute with him over the matter, and he never returned to office.

It was clear that there was simply no intention on the part of the new ANC leadership to investigate corruption or prosecute it. If anything, the party made every possible attempt to ensure that Advocate Vusi Pikoli, the man who replaced Bulelani Ngcuka as National Director of Public Prosecutions, was removed from his post despite being found to have been fit for the job by the Ginwala Enquiry (2008).

Pikoli was for a time replaced by Advocate Menzi Simelane, a person the courts deemed not fit and proper for the role in light of having lied under oath during the inquiry into Pikoli's fitness for office, referred to above. The courts eventually found that the President had not properly applied himself and the appointment was set aside (Constitutional Court of South Africa, 2012).

By 2016, when the term 'state capture' was in vogue, most people seemed to think of more immediate cases, such as SARS (see Chapter 15). In my view, the phenomenon of decimating law enforcement and prosecutorial agencies had been in process for a very long time. An environment in which the corrupt could act with impunity was being steadily created, but as it happens with grand schemes over a long time, it is difficult for most ordinary people to keep track and continually connect the dots. 
This is yet another reason, the third, why no one raised the spectre of "state capture" at the time. Facilitating institutional weakness through a gradual erosion of integrity, governance and installing key capture allies is a process that has been happening under our noses for a while, without the picture coming into full view.

\subsection{BLACK ECONOMIC EMPOWERMENT AS A COVER FOR CRONYISM}

The fourth reason is one of the most common, generally known as BEE - black economic empowerment. The exclusion of black people from the mainstream economy continues for various reasons, and it remains critical that the government's policies advance their meaningful inclusion.

It is common cause that one of the most effective ways for doing this is to mandate that state and private enterprises ensure that a certain percentage of their suppliers are either black-owned or have a significant black and woman shareholding. It was generally under the cover of this rule that some apparent state capture initiatives were pursued.

In July 2015, Moneyweb published a story to which they appended a letter from industrial giant, Bidvest, to SAA in which the former questioned a "request" from the airline that it sets aside $30 \%$ of its procurement business for allocation to blackowned businesses (Slabbert, 2015). To demonstrate the difference between "real" BEE and what appears to have been attempts to shake down suppliers for shareholding, I extract part of the article below:

In the letter the company explains that BidAir Services is a 100\% owned subsidiary of Bidvest Ltd and only the parent company can make decisions about ownership and shareholding.

It further states that BidAir Services is already $63.42 \%$ black-owned and a transfer of a further $30 \%$ to a black-owned small business will therefore result in $74.39 \%$ black shareholding. "Does this imply that SAA's supplier black ownership requirement is now closer to $75 \%$ ?" Bidvest asks.

It explains that BidAir Services provides similar services to other airlines and a new company would therefore have to be established for the SAA contract to accommodate a $30 \%$ partner, which the SAA will apparently nominate. The company asks questions about, among others, the ability of the unknown black small business to contribute to the capital cost such a new company would incur, estimated at R20 million.

In its response to questions from Moneyweb, SAA said: "We confirm that the company is in receipt of correspondence dated 30 June from Bidvest which canvassed a number of issues regarding SAA transformation requirements. SAA is neither oblivious nor in doubt of the BEE ownership of Bidvest. The intent was hardly to influence the existing shareholding at 
Bidvest. If anything, SAA's intention is to contribute to transformation of services rendered by Bidvest to SAA. The $30 \%$ applies to (the) SAA contract, not to Bidvest as a company. (Slabbert, 2015)

At Business Day, where I was editor at the time, we also covered the story. The National Treasury, which is responsible for setting government procurement policy, confirmed that this was not official government policy and could not be pursued unless it was. Nonetheless, reports of such "requests" continued to persist.

In June 2019, the former Head of Procurement at SAA, Dr Masimba Dahwa, testified before the Zondo Commission of Inquiry into State Capture that apart from being a "request", within SAA, this was an "order" from the Board (Zondo Commission, 2019). Testimony at the Commission was continuing at the time of writing, and it was yet to reach its conclusions on the matter.

The point of this example is not to prove that certain individuals were responsible for "state capture" at SAA, but merely to demonstrate how difficult it would be for most people to claim that they were not against transformation under such circumstances. Because black people continue to have limited participation in the mainstream economy, many black people simply will not bother all that much about a case where a "white-owned" company is being compelled to have an even higher level of black shareholding, even if no rule exists to make it so.

It is even more remote that people will have the means to ascertain whether the companies that eventually benefit from such interventions are owned by real entrepreneurs or those who have access to people with political power and therefore are benefiting from cronyism. As an editor who published many stories that questioned what was going on throughout the government at the time, I was often labelled "a puppet of white monopoly capital" by supporters of "radical economic transformation" on Twitter and other social media platforms. Our reporters suffered a similar fate, too.

The intensity of the cyber bullying required targets to develop a thick skin. It goes without saying that it is especially difficult for a white South African to question such actions for fear that the "anti-transformation" label will stick.

In 2018, I attended the gala dinner that marked the end of the Black Management Forum's Elective Conference where its new President, Andile Nomlala, spoke frankly about the years of state capture. He emphasised the importance of "real" transformation where black entrepreneurs were afforded a fair opportunity to participate in the economy, but he was also clear that the conspiracy of silence during the years of state capture was not acceptable. In subsequent public engagements, he has continued to advocate for transformation that is free of political favouritism and corruption. 
During the years of state capture there were not many like him, and one can only wonder how different things may have turned out had his voice been heard sooner. Judging by the reaction of the audience, he would have had no shortage of supporters.

\subsection{BLACK SOLIDARITY AND "RADICAL ECONOMIC TRANSFORMATION"}

In his 1993 book, Race Matters, Dr Cornell West writes about the cynical nomination of Judge Clarence Thomas to the US Supreme Court in order to replace Judge Thurgood Marshall, in what he referred to as "failure of nerve of black leadership" (West, 2017, p. 90). This was because no black leaders or commentators had the courage to challenge Judge Thomas's nomination on account of his poor competence for the role.

Judges Marshall and Thomas are both black. The former had been an esteemed lawyer in the civil rights movement, while the latter was the ultimate antithesis, apart from his track record of incompetence, which was available for inspection at the time. West notes:

The very fact that no black leader could utter publicly that a black appointee for the Supreme Court was unqualified shows how captive they are to white racist stereotypes about black intellectual talent. The point here is not simply that if Thomas were white, they would have no trouble shouting this fact from the rooftops. The point is also that their silence reveals that black leaders may entertain the possibility that the racist stereotype may be true. (West, 2017, p. 24)

He continues:

Of course, some privately admit his mediocrity while pointing out the mediocrity of Justice Souter and other members of the Court - as if white mediocrity were a justification of black mediocrity. No double standards here, the argument goes, if a black man is unqualified one can defend and excuse him by appealing to other unqualified white judges. This chimes well with a cynical tokenism of the lowest common denominator - with little concern for the goal of shattering the racist stereotype or for furthering the public interest of the nation. the public interest of the nation. It also renders invisible highly qualified black judges who deserve serious consideration for selection to the Court. (West, 2017, p. 24)

On this point, I will draw from my own personal experience when I was editor of Business Day. On 24 August 2014, Cabinet announced the appointment of Tshediso Matona as the Chief Executive Officer of Eskom. Matona is a long-standing public servant and was the Director General (DG) of Public Enterprises, the department that oversees Eskom. 
At the time of his appointment, Mr Matona already held a Master's Degree in Development Economics from the University of East Anglia (UK, 1994), a Bachelor/ Honours degree in Economics and Political Science from the University of Cape Town (1992). He had also completed various certificates including in Executive Management (2005) and Infrastructure Development (2011) from Harvard University's Kennedy School of Government (USA). He was the former DG of the Department of Trade and Industry, a post he held from 2006-2010 before serving as Trade Diplomat for South Africa at the UN and World Trade Organisation in Geneva.

I also wish to add that there was never a whiff of impropriety that I was aware of in relation to his tenure in government. However, I felt that for an industrial institution that was already in crisis, the government should have appointed someone with extensive industrial experience who had managed large capital budgets and complex operations. He had none of this experience. I desperately wanted to publish an editorial saying exactly that, but I stopped the process. I realised that there would be a significant body of opinion that Business Day was "pulling down" a suitably qualified black Executive. Of course, my view was not ad hominem at all, and was a technical one, but I ended up thinking that the storm created would defeat the purpose of the editorial. In the end we never wrote it.

This self-policing is common. It is part of the reason why, unless an appointee was hopelessly unqualified, it was difficult to question the suitability of appointees during the years in which state capture occurred. In a society where racial stereotyping and racism are still rife, one has to be extremely careful about expressing public opinion about the suitability or otherwise of black appointees to senior roles, however well meaning.

It was particularly difficult for an editor of a newspaper that fell under the colloquial "white media" pejorative, where, however well argued the case, it would be almost automatically dismissed as expressing the views of "racist white owners" of the newspaper. It has taken people a very long time to accept that some of the people they were happy to see ascend to dizzy heights, were either unqualified or rogue. There was a time when, I believe, many people simply "refused" to listen.

The revelations contained in the Public Protector's State of Capture (2016) report were not all new. Various newspapers, especially the Mail \& Guardian, had been publishing detailed stories about the same networks and their alleged corruption for many years. It felt as if people had become numb to it all. Others, it seemed, were perpetually angry about what they felt was "racist stereotyping". Whatever the reasons were, the outcome that is beyond doubt is that there were few loud voices outside the media until it was too late. 
One of the fundamental questions to reflect upon following the years of state capture is how black people can regain a positive sense of self that does not rely on the worst examples of whiteness. This is too often the criteria used to determine which position black people are going to take in relation to other black people who wilfully fulfil racist stereotypes about what black people do when they get an opportunity to govern.

These stereotypes say black people are incapable of governing effectively. When they get the opportunity to govern, they steal public finances and collapse economies, which is largely what happened over the last ten years. It has to be possible to separate the economic empowerment of black people, which is absolutely non-negotiable, from looting by people who use their blackness as cover to escape accountability. For Zuma, radical economic transformation became the legitimating narrative of state capture.

The all-winning card to play was to make angry remarks about white domination of the economy as cover for the looting, which invariably involved collusion with corrupt white people or foreigners. Once this card was played, the often-abused card of "black excellence" was also brought out in defence of people who, it has now come to pass, never had the interests of black people in their hearts to begin with. Instead, they often tormented those black people who actually deserved to be hailed as examples of black excellence.

This shameful spectacle continues to instances where black professional associations and newspapers are lobbied to fight for their reinstatement while nothing, absolutely nothing is said about and for the many black professionals who were hounded out of their jobs for refusing to engage in corruption. An almost untold aspect of some of the testimony before the Zondo Commission is the long list of victims and their stories of torment at the hands of the corrupt. These are strong, ethically upstanding and committed servants of the South African public who were harassed, victimised, threatened and ejected out of state and public institutions, some of whom underwent immense personal strain over a very long time.

There is Dr Masimba Dahwa who was Chief Procurement Officer at SAA for some of the ruinous time Ms Dudu Myeni was Chairperson. Upon refusing to obey patently unlawful instructions that included awarding contracts to companies chosen by Ms Myeni without following procedures, he was victimised, harassed and hounded out of that organisation. He left for Zimbabwe for a short time fearing for his life, as was heard in his testimony at the Zondo Commission (Zondo Commission, 2019:263).

How did we get to this dark, self-destructive space? How did so many of us black people become captive to cheap tricks that rely on evoking the emotional trauma of racism in order to cause us to submit to people who are, essentially, anti-black? 
The most central reason for this degenerative state is our history of racial oppression itself, whose purpose was to destroy any sense of black communal and cultural cohesion. Today, so-called black radicalism sometimes amounts to a foul-mouthed argument for mediocre, corrupt black people to fill the roles of and behave like corrupt, mediocre apartheid apparatchiks. Through our silence or tacit support of these corrupt elites, we perpetuate rather than stop the destruction of black people's social and ethical fabric, relegating it to mimicking the worst vices of our racist oppressors.

At the same time, competent black people are left to rot on the vine because they do not have access to the patronage system that places the incompetents above them, or they refuse to bow and scrape to low-esteemed politicians who prefer to be treated like 17 th century monarchs and overlords.

In this way, we teach legions of young people, some of whose sole lived experience is a political system that hails and elevates the corrupt and incompetent, that black leadership is inherently corrupt and unable to govern effectively. They see and experience this not because they are told, but because we have chosen to place in leadership those who will, through their actions, give credence to this racist stereotype.

\subsection{CONCLUSION: NOBODY COULD HAVE SAID ANYTHING}

While the history of how we came to gradually accept state capture and the rampant corruption it facilitates, the reality is that there are other reasons why it would nonetheless have been difficult in any event. The following is my sixth reason.

I believe that human beings are more likely to believe that others are sincere, than not. Even when there is a whiff of suspicion, such as when the Scorpions were disbanded, many people appear to have convinced themselves that their replacement, the Hawks, could do the job. This was naïve in the extreme. Knowing how desperate Zuma and many of his allies were to escape prosecution, as well as others who had been part of the ANC's "dealership" culture, there was no way they would have wanted to maintain strong law enforcement and prosecution capacity.

But people persevered in the mistaken belief that state capture actors, veiled as some of them were, would act against their own interests. This phenomenon has been the subject of many an academic study and is well established.

Peter Ditto and David Lopez (1992) compared two groups of study participants between whom favourable and unfavourable medical tests results were divided. People belonging to the group that had been told that they had a (fictitious) illness were more likely to rate the test as less accurate. In contrast, those who were given 
a clean bill of health instantly believed that it was accurate and were far less likely to seek a second opinion, unlike the first group. "It takes more information to make you believe something you don't want to believe than something you do," Ditto said (1992, n.p.).

One of the pillars of investigation of the State Capture Inquiry is to find out if President Jacob Zuma's Cabinet reshuffles were informed by the need to serve private interests. When the Public Protector published her report and touched on this very issue, there were people who were genuinely surprised, but they should have never been. If Schabir Shaik was convicted in 2005 of bribing him with small amounts of money over time, surely a logical person would easily conclude that larger amounts of money would induce him to do considerably more?

One would think so, but human beings do not generally think that way. This type of detailed, curious enquiry to reach nuanced and clear-headed conclusions is the preserve of a few who may do so for professional reasons or have peculiar intellectual interests.

Knowing this, a more enduring question is whether we will ever not be vulnerable to state capture happening in future? 


\section{References}

ANC (2021) African National Congress Deployment to Committees. [Online]. https://bit.ly/3iumRTN (Accessed 3 May 2021).

Basson, A. (2010) Selebi sentenced to 15 years, Mail \& Guardian. [Online]. https://bit.ly/ 3scPRTz (Accessed 5 December 2020).

Constitutional Court of South Africa (2012) Democratic Alliance $v$ President of the Republic of South Africa and Others Case CCT 122/11: Media Summary, Constitutional Court of South Africa.

Ditto, P.H. \& Lopez, D.F. (1992) 'Motivated skepticism: Use of differential decision criteria for preferred and nonpreferred conclusions', Journal of Personality and Social Psychology, 63(4):568-584. [Online]. https://doi.org/ 10.1037/0022-3514.63.4.568 (Accessed 21 April 2020).

Ginwala Enquiry (2008) 'Report of Enquiry into the fitness of Advocate VP Pikoli to hold the office of National Director of Public Prosecutions', thepresidencygov. Pretoria.

Hellman, J. \& Kaufmann, D. (2001) Confronting the Challenge of State Capture in Transition Economies, International Monetary Fund (IMF) - International Finance \& Development. [Online]. https://bit.ly/ 2Xa2d3n (Accessed 2 November 2020).

High Court of South Africa: Natal Provincial Division (2005) 'National Director of Public Prosecutions v Schabir Shaik and Others CC 27/04 Durban and Coast Local Division, 31 January 2006 (Squires Judgment)', High Court of South Africa. [Online]. https:// bit. ly/3lGrhJl (Accessed 12 December 2019).

Maphunye, K.J. (2002) The Features of South Africas post-1994 Civil Service and the Challenges it faces in the New Dispensation, African Training and Research Centre in Administration for Development. African Training and Research Centre in Administration for Development.

Mbeki, T. (2007) Opening address and political report of ANC President Thabo Mbeki by $A N C, 16$ December, 52nd National Conference, Polokwane, African National
Congress (ANC). [Online]. https://bit.ly/ 3yxGShR (Accessed 2 November 2020).

Motlanthe, K. (2002) 'Secretary General's Organisational Report to the 51st ANC National Conference', African National Congress (ANC). [Online]. https://bit.ly/ 3jAudEv (Accessed 2 November 2020).

Office of the Inspector General of Intelligence (OIGI) (2006) Executive Summary of the Final Report on the Findings of an Investigation into the legality of the surveillance operations carried out by the National Intelligence Agency (NIA) on $\mathrm{Mr}$ Sakumzi Macozoma. https://bit.ly/3iwbX04

Paton, C. (2007) ANC and Business: Soul for Sale, Financial Mail. [Online]. https://bit.ly/ 3iunv3F (Accessed 21 April 2020).

Pikoli, V. \& Wiener, M. (2013) My Second Initiation: The Memoir of Vusi Pikoli. Johannesburg: Picador Africa.

Public Protector (2016) State of Capture, Public Protector. Pretoria. [Online]. https://bit.ly/ 3rXPz2y (Accessed 1 September 2018).

Republic of South Africa (2005) Prevention and Combating of Corrupt Activities Act [No. 12 OF 2004], Government Gazette. [Online]. https://bit.ly/3AlJu2V (Accessed 29 August 2018).

Roelf, W. (2008) 'South Africa's Scorpion crimefighters to be disbanded', Reuters. [Online]. https://reut.rs/3AchTRM (Accessed 2 November 2020).

SABC Digital News (2016) 'Mcebisi Jonas on being offered a job by the Guptas', YouTube. [Online]. https://bit.ly/3xvbv6m (Accessed 1 December 2017).

Slabbert, A. (2015) 'SAA confirms 30\% Bidvest contract demand', Moneyweb. [Online]. https://bit.ly/3CnS5UB (Accessed 2 November 2020).

Sole, S. and Dawes, N. (2005) 'A picture of a grand conspiracy', Mail \& Guardian. [Online]. https://bitly/2X6A1hJ (Accessed 21 April 2020).

West, C. (2017) Race matters, 25th anniversary: With a new introduction. Beacon Press. 
Zondo Commission (2019) 'Transcript from Inquiry into State Capture: Day 123 (28-06-2019) - Testimony of Daniel Mahlangu \& Masimba Dahwa.' Commission of Inquiry into State Capture. Johannesburg: Commission of Inquiry into State Capture. 


\section{APPENDIX}

\begin{tabular}{|c|c|c|c|c|}
\hline $\begin{array}{l}\text { Case Study } \\
\text { in State } \\
\text { Capture }\end{array}$ & Status & Summary Description & $\begin{array}{l}\text { Investigation } \\
\text { Body / } \\
\text { Source of } \\
\text { Evidence }\end{array}$ & $\begin{array}{l}\text { Government } \\
\text { Entity } \\
\text { Implicated }\end{array}$ \\
\hline \multicolumn{5}{|c|}{ Scandals Connected to Jacob Zuma, Guptas, Other Key Networks and ANC Politics } \\
\hline $\begin{array}{l}\text { The State } \\
\text { of Capture } \\
\text { report - } \\
\text { focuses } \\
\text { on Guptas' } \\
\text { relationship } \\
\text { with Jacob } \\
\text { Zuma and } \\
\text { their alleged } \\
\text { influence on } \\
\text { the affairs } \\
\text { of state }\end{array}$ & $\begin{array}{l}\text { First complaint } \\
\text { was received } \\
\text { in March } 2016 \\
\text { and the report } \\
\text { was released in } \\
\text { November } 2016 .\end{array}$ & $\begin{array}{l}\text { Investigation into complaints of alleged improper } \\
\text { and unethical conduct by the President and } \\
\text { other State Functionaries, relating to alleged } \\
\text { improper relationships and involvement of the } \\
\text { Gupta Family in the removal and appointment } \\
\text { of Ministers and Directors of State-Owned } \\
\text { Enterprises (SOEs), resulting in improper and } \\
\text { possibly corrupt award of State Contracts and } \\
\text { Benefits to the Gupta Family's Businesses. } \\
\text { The report details numerous allegations of } \\
\text { the Guptas' involvement in affairs of the state } \\
\text { and their irregular activities that enable rent } \\
\text { extraction. The findings were not conclusive } \\
\text { and the remedial action was to establish a } \\
\text { commission of inquiry into state capture (to } \\
\text { be appointed by the President, but with a } \\
\text { judge selected by the Chief Justice). Litigation } \\
\text { endeavoured to delay or prohibit the report's } \\
\text { release and implementation of remedial actions, } \\
\text { but failed, and the commission was established } \\
\text { in } 2018 \text {. }\end{array}$ & $\begin{array}{l}\text { - Public } \\
\text { Protector, } \\
\text { followed by } \\
\text { litigation }\end{array}$ & $\begin{array}{l}\text { - GCIS (The } \\
\text { New Age) } \\
\text { - Eskom } \\
\text { (Optimum) } \\
\text { - Transnet } \\
\text { (Regiments/ } \\
\text { Trillian) } \\
\text { - Denel } \\
\text { - SAA (The } \\
\text { New Age) } \\
\text { - SABC (The } \\
\text { New Age) } \\
\text { - Department of } \\
\text { Finance } \\
\text { - Transport } \\
\text { (SAA) } \\
\text { - Communica- } \\
\text { tions (SABC } \\
\text { \& GCIS) }\end{array}$ \\
\hline $\begin{array}{l}\text { Zondo } \\
\text { Commission }\end{array}$ & $\begin{array}{l}\text { Established } \\
\text { in 2018, with } \\
\text { anticipated } \\
\text { conclusion being } \\
\text { the end of } 2021 .\end{array}$ & $\begin{array}{l}\text { Formally titled the Judicial Commission of } \\
\text { Inquiry into Allegations of State Capture, } \\
\text { Corruption and Fraud in the Public Sector } \\
\text { including Organs of State, the Commission } \\
\text { was promulgated by then President Zuma in } \\
\text { response to the remedial actions as outlined in } \\
\text { the Public Protector's State of Capture report. } \\
\text { As of June } 2021 \text {, the Commission that started } \\
\text { in August } 2018 \text { has held more than } 418 \text { days } \\
\text { of hearings of over } 330 \text { testimonies (generating } \\
\text { over } 71000 \text { pages of transcript). The inquiry's } \\
\text { terms of reference were expansive and, as } \\
\text { such, the scope of investigations went beyond } \\
\text { merely looking into the Gupta-related cases, } \\
\text { covering other networks (e.g., Bosasa) as well } \\
\text { as other government institutions (e.g., role } \\
\text { of Parliament). }\end{array}$ & $\begin{array}{l}\text { - Zondo } \\
\text { Commission }\end{array}$ & $\begin{array}{l}\text { Various } \\
\text { work-streams } \\
\text { covering } \\
\text { inter alia: } \\
\text { - SOEs } \\
\text { (Eskom, } \\
\text { Transnet, } \\
\text { Denel, SAA) } \\
\text { - Free State } \\
\quad \text { Provincial } \\
\text { Government } \\
\text { - Bosasa } \\
\text { - SARS } \\
\text { - Law } \\
\text { enforcement } \\
\text { - State Security } \\
\text { Agency (SSA) } \\
\text { - The New Age } \\
\text { \& ANN7 } \\
\text { - Role of } \\
\text { Parliament } \\
\text { and ANC }\end{array}$ \\
\hline
\end{tabular}




\begin{tabular}{|c|c|c|c|c|}
\hline $\begin{array}{l}\text { Case Study } \\
\text { in State } \\
\text { Capture }\end{array}$ & Status & Summary Description & $\begin{array}{l}\text { Investigation } \\
\text { Body / } \\
\text { Source of } \\
\text { Evidence }\end{array}$ & $\begin{array}{l}\text { Government } \\
\text { Entity } \\
\text { Implicated }\end{array}$ \\
\hline \multicolumn{5}{|c|}{ Scandals Connected to Jacob Zuma, Guptas, Other Key Networks and ANC Politics } \\
\hline Bosasa & $\begin{array}{l}\text { Dating back to a } \\
2009 \text { SIU report. } \\
\text { Investigations and } \\
\text { various litigations } \\
\text { are ongoing. }\end{array}$ & $\begin{array}{l}\text { In 2019, former Bosasa C00, Anglo Agrizzi, } \\
\text { testified at the Zondo Commission, detailing } \\
\text { the acts and long history of corruption between } \\
\text { various Bosasa companies predominantly } \\
\text { owned by Gavin Watson, and numerous } \\
\text { government entities/departments. The } \\
\text { testimony of Agrizzi (and other former Bosasa } \\
\text { employees) corroborated the findings of a } \\
2009 \text { SIU investigation that alleged corruption } \\
\text { in several contracts Bosasa had with the } \\
\text { Department of Correctional Services. Criminal } \\
\text { court proceedings have been initiated based } \\
\text { on the } 2009 \text { SIU investigation, along with new } \\
\text { investigations initiated by SARS and other law } \\
\text { enforcement entities. }\end{array}$ & $\begin{array}{l}\text { - Special } \\
\text { Investi- } \\
\text { gation } \\
\text { Unit (SIU) } \\
\text { - Zondo } \\
\text { Commission }\end{array}$ & $\begin{array}{l}\text { - Department of } \\
\text { Correctional } \\
\text { Services } \\
\text { - Department of } \\
\text { Justice } \\
\text { - Department of } \\
\text { Home Affairs } \\
\text { - Department of } \\
\text { Transport } \\
\text { - Various SOEs } \\
\text { (e.g., SAPO, } \\
\text { ACSA) } \\
\text { - National } \\
\text { Prosecuting } \\
\text { Authority } \\
\text { (NPA) } \\
\text { - Members of } \\
\text { Parliament }\end{array}$ \\
\hline Arms Deal & $\begin{array}{l}\text { Various } \\
\text { investigations and } \\
\text { sources, dating } \\
\text { back to 1990s. } \\
\text { Most significant } \\
\text { source being } \\
\text { through Seriti } \\
\text { Commission. } \\
\text { Corruption case } \\
\text { against Zuma is } \\
\text { ongoing. }\end{array}$ & $\begin{array}{l}\text { Commission of Inquiry into allegations of fraud, } \\
\text { corruption, impropriety, or irregularity in the } \\
\text { Strategic Defence Procurement Packages } \\
\text { (SDPP). Various court cases related to } \\
\text { allegations of corruption against Jacob Zuma. } \\
\text { On Monday, } 24 \text { October 2011, the President } \\
\text { announced the Commission chaired by Judge } \\
\text { Seriti. The findings of the Commission were that } \\
\text { there was "no evidence" of corruption, but this } \\
\text { is seen by many to have been a whitewash. The } \\
\text { report was taken on review and set aside in } \\
\text { August 2019. The corruption case against Zuma } \\
\text { is ongoing before the courts. }\end{array}$ & $\begin{array}{l}\text { - Seriti } \\
\text { Commission } \\
\text { - Various } \\
\text { court cases }\end{array}$ & $\begin{array}{l}\text { Initially: } \\
\text { - South African } \\
\text { National } \\
\text { Defence } \\
\text { Force } \\
\text { - Members of } \\
\text { Parliament } \\
\text { Allegations also } \\
\text { involve: } \\
\text { - NPA } \\
\text { - SSA }\end{array}$ \\
\hline $\begin{array}{l}\text { Nkandla } \\
\text { Security } \\
\text { Upgrades }\end{array}$ & $\begin{array}{l}\text { Investigation } \\
\text { started in } \\
\text { November } 2012 . \\
\text { Report on } \\
\text { investigation } \\
\text { was released in } \\
\text { March } 2014 .\end{array}$ & $\begin{array}{l}\text { Report on security upgrades to President } \\
\text { Zuma's homestead in Nkandla. The investigation } \\
\text { found that the President unduly benefited from } \\
\text { the upgrades and as part of remedial actions } \\
\text { the President was required to pay back a portion } \\
\text { of the costs of the upgrades. Zuma instructed } \\
\text { that SAPS undertake their own investigation, } \\
\text { which sought to rationalise the expenses (fire- } \\
\text { pool report). Parliament accepted this alternative } \\
\text { report, but major court cases followed, } \\
\text { ultimately declaring that the Public Protector's } \\
\text { remedial actions are binding. President and } \\
\text { Parliament failed to uphold the Constitution. } \\
\text { President ordered to "pay back the money". }\end{array}$ & $\begin{array}{l}\text { - Public } \\
\text { Protector's } \\
\text { Secured } \\
\text { in Comfort } \\
\text { report, } \\
\text { followed by } \\
\text { litigation }\end{array}$ & $\begin{array}{l}\text { - Department of } \\
\text { Public Works } \\
\text { - South African } \\
\text { Police Service }\end{array}$ \\
\hline
\end{tabular}




\begin{tabular}{|c|c|c|c|c|}
\hline $\begin{array}{l}\text { Case Study } \\
\text { in State } \\
\text { Capture }\end{array}$ & Status & Summary Description & $\begin{array}{l}\text { Investigation } \\
\text { Body / } \\
\text { Source of } \\
\text { Evidence }\end{array}$ & $\begin{array}{l}\text { Government } \\
\text { Entity } \\
\text { Implicated }\end{array}$ \\
\hline \multicolumn{5}{|c|}{ Scandals Connected to Jacob Zuma, Guptas, Other Key Networks and ANC Politics } \\
\hline $\begin{array}{l}\text { Private } \\
\text { Aircraft } \\
\text { Landing at } \\
\text { Waterkloof } \\
\text { Airforce Base } \\
\text { and Gupta } \\
\text { Sun City } \\
\text { Wedding }\end{array}$ & May 2013. & $\begin{array}{l}\text { In 2013, justice, crime prevention, and } \\
\text { security cluster (JCPS) - a cabinet structure } \\
\text { composed of various ministries - undertook an } \\
\text { investigation into the Landing of a Commercial } \\
\text { aircraft at Air Force Base Waterkloof (report } \\
\text { titled the same). The investigation revealed that } \\
\text { the Guptas initially tried to organise a special } \\
\text { landing at OR Tambo International Airport, but } \\
\text { was turned down. They then approached the } \\
\text { Indian High Commission who re-designated the } \\
\text { wedding entourage as an official delegation to } \\
\text { secure a landing at the Waterkloof base. The } \\
\text { wedding held at Sun City was attended by a } \\
\text { number of high-profile ANC politicians and was } \\
\text { paid for in part by moneys looted from the Vrede } \\
\text { Dairy Farm project. }\end{array}$ & $\begin{array}{l}\text { - Report by } \\
\text { JPCS } \\
\text { - Zondo } \\
\text { Commission }\end{array}$ & $\begin{array}{l}\text { - Department of } \\
\text { International } \\
\text { Relations and } \\
\text { Cooperation } \\
\text { (DIRCO) } \\
\text { - Department of } \\
\text { Defence } \\
\text { - Department of } \\
\text { Transport }\end{array}$ \\
\hline $\begin{array}{l}\text { Free State } \\
\text { Provincial } \\
\text { Capture, } \\
\text { includes } \\
\text { Vrede Dairy } \\
\text { Farm and } \\
\text { Asbestos } \\
\text { Contracts }\end{array}$ & Ongoing. & $\begin{array}{l}\text { The Vrede Dairy Farm project was initiated } \\
\text { by the Free State Provincial Government as a } \\
\text { development project, however, in partnering with } \\
\text { a Gupta-linked company Estina, government } \\
\text { funds were looted. In 2018, the Public } \\
\text { Protector released a report on their } 2018 \\
\text { investigation, but it was taken on review and } \\
\text { set aside by the courts. The second part of the } \\
\text { investigation is yet to be finalised. The NPA } \\
\text { laid criminal charges against Gupta associates } \\
\text { and implicated government officials. Court } \\
\text { proceedings are ongoing. } \\
\text { Significant testimony and evidence have been } \\
\text { presented at the Zondo Commission regarding } \\
\text { the Vrede Farm case, as well as the asbestos } \\
\text { inspection project (criminal proceedings are also } \\
\text { underway). Both projects implicate high-profile } \\
\text { politicians and senior officials manipulating } \\
\text { government process. }\end{array}$ & $\begin{array}{l}\text { - } \text { Public } \\
\text { Protector } \\
\text { reports } \\
\text { - Zondo } \\
\text { Commission } \\
\text { - Various } \\
\text { court cases }\end{array}$ & $\begin{array}{l}\text { - Free State } \\
\text { Provincial } \\
\text { Government }\end{array}$ \\
\hline $\begin{array}{l}\text { Irregular } \\
\text { removal of } \\
\text { National } \\
\text { Director } \\
\text { of Public } \\
\text { Prosecutions } \\
\text { (NDPP), } \\
\text { Mxolisi } \\
\text { Nxasana }\end{array}$ & $\begin{array}{l}\text { Inquiry instituted } \\
\text { in February } 2015, \\
\text { but was cancelled } \\
\text { in May } 2015 . \\
\text { This triggers the } \\
\text { Constitutional Court } \\
\text { cases that followed. }\end{array}$ & $\begin{array}{l}\text { Inquiry into the fitness of Mxolisi Nxasana to } \\
\text { hold office as NDPP. The Inquiry was cancelled } \\
\text { after Zuma "agreed to let Nxasana resign". He } \\
\text { was paid R17m - the balance of his ten-year } \\
\text { contract. Court cases followed detailing the } \\
\text { abuse of the presidency powers by Zuma. } \\
\text { Ultimately, Nxasana was ordered to repay } \\
\text { R17m and Zuma's appointed replacement, } \\
\text { Shawn Abrahams, was ordered to vacate office. } \\
\text { Constitutional Court found Zuma's actions to } \\
\text { be an abuse of power and in breach of his } \\
\text { constitutional obligations. }\end{array}$ & $\begin{array}{l}\text { - Cassim } \\
\text { Inquiry into } \\
\text { fitness of } \\
\text { Mxolisi } \\
\text { Nxasana to } \\
\text { hold office } \\
\text { of NDPP } \\
\text { initiated } \\
\text { by Zuma, } \\
\text { followed by } \\
\text { litigation }\end{array}$ & $\begin{array}{l}\text { - National } \\
\text { Prosecution } \\
\text { Authority }\end{array}$ \\
\hline $\begin{array}{l}\text { Political } \\
\text { killings in } \\
\text { KZN }\end{array}$ & $\begin{array}{l}\text { Established in } \\
\text { October } 2016 . \text { The } \\
\text { report was released } \\
\text { in May } 2018 .\end{array}$ & $\begin{array}{l}\text { On } 28 \text { October 2016, the Premier of the } \\
\text { Province of KwaZulu-Natal established a } \\
\text { Commission of Enquiry into the Underlying } \\
\text { Causes of the Murder of Politicians in KwaZulu- } \\
\text { Natal (KZN). }\end{array}$ & $\begin{array}{l}\text { - Moerane } \\
\text { Commission } \\
\text { of Enquiry }\end{array}$ & $\begin{array}{l}\text { - KZN Provincial } \\
\text { Government } \\
\text { - KZN Local } \\
\text { Governments }\end{array}$ \\
\hline
\end{tabular}




\begin{tabular}{|c|c|c|c|c|}
\hline $\begin{array}{l}\text { Case Study } \\
\text { in State } \\
\text { Capture }\end{array}$ & Status & Summary Description & $\begin{array}{l}\text { Investigation } \\
\text { Body / } \\
\text { Source of } \\
\text { Evidence } \\
\end{array}$ & $\begin{array}{l}\text { Government } \\
\text { Entity } \\
\text { Implicated }\end{array}$ \\
\hline \multicolumn{5}{|c|}{ Scandals Connected to Jacob Zuma, Guptas, Other Key Networks and ANC Politics } \\
\hline \multicolumn{5}{|c|}{ State Capture of State-Owned Enterprises and Government Departments } \\
\hline $\begin{array}{l}\text { Interference } \\
\text { in operations } \\
\text { at the SABC }\end{array}$ & $\begin{array}{l}\text { The Ad Hoc } \\
\text { Committee was } \\
\text { established in } \\
\text { November } 2016 \\
\text { and final report } \\
\text { was tabled on } \\
24 \text { February } 2017 .\end{array}$ & $\begin{array}{l}\text { Parliamentary Ad Hoc Committee on the } \\
\text { SABC Board Inquiry into mismanagement and } \\
\text { interference in SABC operations. Findings } \\
\text { include evidence of Minister Faith Muthambi's } \\
\text { interference in the organisation and editorial } \\
\text { interference, in the firing of SABC } 8 \text { who } \\
\text { protested censorship of the national broadcaster } \\
\text { (on instruction from COO Hlaudi Motsoeneng). It } \\
\text { should be noted that the inquiry was preceded } \\
\text { by an investigation by the Public Protector. } \\
\text { Details are contained in the } 2014 \text { report titled } \\
\text { When Governance and Ethics Fail. }\end{array}$ & $\begin{array}{l}\text { - Parliamen- } \\
\text { tary Inquiry } \\
\text { - Preceded by } \\
\text { an investi- } \\
\text { gation by } \\
\text { the Public } \\
\text { Protector }\end{array}$ & $\begin{array}{l}\text { - SABC } \\
\text { (Department } \\
\text { of Communi- } \\
\text { cation) }\end{array}$ \\
\hline \multirow[t]{2}{*}{$\begin{array}{l}\text { Passenger } \\
\text { Rail Agency } \\
\text { of South } \\
\text { Africa } \\
\text { (PRASA) }\end{array}$} & $\begin{array}{l}\text { Complaints were } \\
\text { lodged in } 2012 \\
\text { and the report } \\
\text { was released in } \\
\text { August } 2015 .\end{array}$ & $\begin{array}{l}\text { Several cases of "mismanagement and } \\
\text { irregularities" regarding various contracts. } \\
\text { Lucky Montana was CEO at the time. One of } \\
\text { the remedial actions stipulated that National } \\
\text { Treasury was to investigate all PRASA contracts } \\
\text { from } 2012 \text { onwards with a value of R10 million } \\
\text { or more. National Treasury implemented the } \\
\text { remedial action which resulted in several } \\
\text { investigations, the details of which were leaked } \\
\text { to the public. }\end{array}$ & $\begin{array}{l}\text { - Public } \\
\text { Protector's } \\
\text { Derailed } \\
\text { report on } \\
\text { PRASA } \\
\text { - Numerous } \\
\text { investiga- } \\
\text { tions }\end{array}$ & $\begin{array}{l}\text { - PRASA } \\
\text { - Department of } \\
\text { Transport }\end{array}$ \\
\hline & $\begin{array}{l}\text { In June } 2017, \\
\text { Parliament directed } \\
4 \text { committees to } \\
\text { investigate state } \\
\text { capture. Committee } \\
\text { hearings were not } \\
\text { completed. }\end{array}$ & $\begin{array}{l}\text { In terms of the parliamentary directive, the } \\
\text { Portfolio Committee on Transport was requested } \\
\text { to establish an Inquiry into State Capture at } \\
\text { PRASA. However, the Portfolio Committee noted } \\
\text { that PRASA was not mentioned in the Public } \\
\text { Protector's State of Capture report and decided } \\
\text { they would focus on the various investigation } \\
\text { reports produced for National Treasury (as } \\
\text { recommended in Derailed report). }\end{array}$ & $\begin{array}{l}\text { - Portfolio } \\
\text { Committee } \\
\text { on Transport }\end{array}$ & $\begin{array}{l}\text { - PRASA } \\
\text { - Department of } \\
\text { Transport }\end{array}$ \\
\hline $\begin{array}{l}\text { Eskom } \\
\text { Inquiry into } \\
\text { State Capture }\end{array}$ & $\begin{array}{l}\text { In June } 2017 \text {, } \\
\text { Parliament directed } \\
4 \text { committees } \\
\text { to investigate } \\
\text { state capture. } \\
\text { Public Enterprises } \\
\text { Committee } \\
\text { report on Eskom } \\
\text { was released in } \\
\text { November } 2018 .\end{array}$ & $\begin{array}{l}\text { Extensive hearings were held by the Committee } \\
\text { detailing much of the evidence presented in } \\
\text { the Public Protector's report. The Committee } \\
\text { presented recommendations and compiled } \\
\text { a final report detailing their findings. These } \\
\text { included findings that Ministers Lynne Brown } \\
\text { and Malusi Gigaba were negligent and had to } \\
\text { be held accountable. Also recommended that } \\
\text { criminal investigations be undertaken against } \\
\text { the relevant Eskom executives. }\end{array}$ & $\begin{array}{l}\text { - Parliamen- } \\
\text { tary Inquiry }\end{array}$ & $\begin{array}{l}\text { - Eskom } \\
\text { - Department } \\
\text { of Public } \\
\text { Enterprises }\end{array}$ \\
\hline $\begin{array}{l}\text { Nugent } \\
\text { Commission } \\
\text { - SARS } \\
\text { Inquiry }\end{array}$ & $\begin{array}{l}\text { The Inquiry was } \\
\text { constituted on } \\
24 \text { May } 2018 \text { and } \\
\text { the final report } \\
\text { was released in } \\
\text { December } 2018 .\end{array}$ & $\begin{array}{l}\text { Commission of Inquiry into tax administration } \\
\text { and governance by South African Revenue } \\
\text { Service (SARS). Tom Moyane was fired based on } \\
\text { the interim report released in September } 2018 . \\
\text { The inquiry found that Moyane, with the help of } \\
\text { consultancy company Bain, had implemented } \\
\text { restructuring of the organisation, resulting in } \\
\text { gross mismanagement and erosion of SARS. } \\
\text { Moyane motivated the restructuring based on } \\
\text { the "rogue unit" narrative that has been the } \\
\text { subject of several other debunked investigations } \\
\text { and the subject of much litigation. }\end{array}$ & $\begin{array}{l}\text { - Judicial } \\
\text { Commission } \\
\text { of Inquiry } \\
\text { - Court cases } \\
\text { around the } \\
\text { "rogue unit" } \\
\text { narrative }\end{array}$ & $\begin{array}{l}\text { - SARS } \\
\text { (National } \\
\text { Treasury) }\end{array}$ \\
\hline
\end{tabular}




\begin{tabular}{|c|c|c|c|c|}
\hline $\begin{array}{l}\text { Case Study } \\
\text { in State } \\
\text { Capture }\end{array}$ & Status & Summary Description & $\begin{array}{l}\text { Investigation } \\
\text { Body / } \\
\text { Source of } \\
\text { Evidence }\end{array}$ & $\begin{array}{l}\text { Government } \\
\text { Entity } \\
\text { Implicated }\end{array}$ \\
\hline \multicolumn{5}{|c|}{ Scandals Connected to Jacob Zuma, Guptas, Other Key Networks and ANC Politics } \\
\hline \multicolumn{5}{|c|}{ State Capture of State-Owned Enterprises and Government Departments } \\
\hline $\begin{array}{l}\text { Commission } \\
\text { of Inquiry } \\
\text { into Public } \\
\text { Investment } \\
\text { Corporation } \\
\text { (PIC) }\end{array}$ & $\begin{array}{l}\text { In October } 2018 \text {, } \\
\text { the Commission } \\
\text { was constituted, } \\
\text { and the final report } \\
\text { was released in } \\
\text { March } 2020 .\end{array}$ & $\begin{array}{l}\text { Commission of Inquiry into allegations of } \\
\text { impropriety regarding Public Investment } \\
\text { Corporation (PIC). There were extensive hearings } \\
\text { on various 'dodgy' deals the PIC entered } \\
\text { into and details of political and executive } \\
\text { interference in the operations and decision- } \\
\text { making processes of the investment agency. }\end{array}$ & $\begin{array}{l}\text { - Judicial } \\
\text { Commission } \\
\text { of Inquiry }\end{array}$ & $\begin{array}{l}\text { - PIC (National } \\
\text { Treasury) }\end{array}$ \\
\hline $\begin{array}{l}\text { South African } \\
\text { Social } \\
\text { Security } \\
\text { Agency } \\
\text { (SASSA) }\end{array}$ & $\begin{array}{l}\text { Various } \\
\text { Constitutional Court } \\
\text { cases from } 2011 \\
\text { to } 2018 \text { resulted } \\
\text { in removal of CPS } \\
\text { as service provider } \\
\text { to SASSA. }\end{array}$ & $\begin{array}{l}\text { In 2014, South African Social Security Agency's } \\
\text { (SASSA) } 2012 \text { contract with CPS was found } \\
\text { to be irregular and invalid, however, due to the } \\
\text { importance of ensuring beneficiaries received } \\
\text { grants, CPS continued to be the service } \\
\text { providers until } 2018 \text {. Following a March } 2017 \\
\text { ruling, the Constitutional Court instituted a } \\
\text { Section } 38 \text { Inquiry into Minister Bathabile } \\
\text { Dlamini's personal liability for the narrowly } \\
\text { averted grant payment crisis. }\end{array}$ & $\begin{array}{l}\text { Primary } \\
\text { sources: } \\
\text { - AllPay court } \\
\text { case } \\
\text { - Black Sash } \\
\text { court case }\end{array}$ & - SASSA \\
\hline $\begin{array}{l}\text { South African } \\
\text { Airways (SAA) } \\
\text { and SAA } \\
\text { Technical }\end{array}$ & $\begin{array}{l}\text { Court case } \\
\text { to have Dudu } \\
\text { Myeni declared a } \\
\text { delinquent director } \\
\text { was launched } \\
\text { in } 2017 .\end{array}$ & $\begin{array}{l}\text { Court case was launched in } 2017 \text { by Outa and } \\
\text { the SAA Pilots' Association (SAAPA) to declare } \\
\text { Myeni a delinquent director in terms of the } \\
\text { Companies Act, based on her actions while she } \\
\text { was chairperson of the SAA Board. In 2020, the } \\
\text { High Court declared Myeni a delinquent director } \\
\text { for life. A significant amount of new evidence } \\
\text { also emerged through the Zondo Commission, } \\
\text { outlining how the operations at SAA were } \\
\text { undermined and how Myeni and others abused } \\
\text { their positions of authority. }\end{array}$ & $\begin{array}{l}\text { - Court } \\
\text { papers } \\
\text { - Zondo } \\
\text { Commission }\end{array}$ & $\begin{array}{l}\text { - SAA } \\
\text { - SAA Technical }\end{array}$ \\
\hline $\begin{array}{l}\text { Gupta Family } \\
\text { Naturalisation }\end{array}$ & $\begin{array}{l}\text { In June } 2017, \\
\text { Parliament directed } \\
4 \text { committees to } \\
\text { investigate state } \\
\text { capture. Final } \\
\text { report was tabled } \\
14 \text { March } 2019 .\end{array}$ & $\begin{array}{l}\text { Portfolio Committee on Home Affairs Inquiry into } \\
\text { the Gupta Family Naturalisation was established } \\
\text { in terms of the Parliamentary directive. Hearings } \\
\text { formally started on } 12 \text { September 2018. Final } \\
\text { report was tabled on } 14 \text { March 2019. Questions } \\
\text { were raised around contracts with Visa } \\
\text { Facilitation Services. This matter is ongoing as } \\
\text { of December } 2020 \text {. }\end{array}$ & $\begin{array}{l}\text { - Portfolio } \\
\text { Committee } \\
\text { on Home } \\
\text { Affairs }\end{array}$ & $\begin{array}{l}\text { - Department of } \\
\text { Home Affairs }\end{array}$ \\
\hline $\begin{array}{l}\text { Inquiry into } \\
\text { State Capture } \\
\text { related to } \\
\text { Gupta-owned } \\
\text { mines }\end{array}$ & $\begin{array}{l}\text { In June } 2017, \\
\text { Parliament directed } \\
4 \text { committees } \\
\text { to investigate } \\
\text { state capture. }\end{array}$ & $\begin{array}{l}\text { Though the Committee drafted a term of } \\
\text { reference for the Inquiry, the activities of holding } \\
\text { hearings and consolidating the evidence never } \\
\text { materialised beyond questions being put to then } \\
\text { Minister Zwane. }\end{array}$ & $\begin{array}{l}\text { - Portfolio } \\
\text { Committee } \\
\text { on Mineral } \\
\text { Resources }\end{array}$ & $\begin{array}{l}\text { - Department } \\
\text { of Mineral } \\
\text { Resources }\end{array}$ \\
\hline
\end{tabular}




\begin{tabular}{|c|c|c|c|c|}
\hline $\begin{array}{l}\text { Case Study } \\
\text { in State } \\
\text { Capture }\end{array}$ & Status & Summary Description & $\begin{array}{l}\text { Investigation } \\
\text { Body / } \\
\text { Source of } \\
\text { Evidence }\end{array}$ & $\begin{array}{l}\text { Government } \\
\text { Entity } \\
\text { Implicated }\end{array}$ \\
\hline \multicolumn{5}{|c|}{ Scandals Connected to Jacob Zuma, Guptas, Other Key Networks and ANC Politics } \\
\hline \multicolumn{5}{|c|}{ State Capture of State-Owned Enterprises and Government Departments } \\
\hline \multirow{3}{*}{$\begin{array}{l}\text { Various } \\
\text { investigations } \\
\text { relating to } \\
\text { State Capture } \\
\text { at Eskom }\end{array}$} & 2015 & $\begin{array}{l}\text { In 2015, Dentons produced an interim report } \\
\text { on their investigations into Status of Business } \\
\text { and Challenges at Eskom. Their investigation } \\
\text { was halted. }\end{array}$ & - Eskom & - Eskom \\
\hline & \multirow[t]{2}{*}{2017} & $\begin{array}{l}\text { In 2017, PricewaterhouseCoopers (PwC) was } \\
\text { appointed by National Treasury to investigate } \\
\text { Eskom's Coal Procurement Processes. Damning } \\
\text { findings were made in relation to Gupta-owned } \\
\text { Tegeta mine contracts and poor coal quality. }\end{array}$ & - Eskom & - Eskom \\
\hline & & $\begin{array}{l}\text { G9 was contracted by Eskom to investigate } \\
\text { the Trillian/McKinsey contracts. Interim report } \\
\text { presented to Board of Eskom in August } 2017 . \\
\text { The investigation remained incomplete, and } \\
\text { no report is available in the public domain. } \\
\text { Evidence from the investigation was presented } \\
\text { in the Parliamentary Inquiry into Eskom } \\
\text { State Capture. }\end{array}$ & $\begin{array}{l}\text { - National } \\
\text { Treasury }\end{array}$ & - Eskom \\
\hline $\begin{array}{l}\text { National } \\
\text { Treasury } \\
\text { Fundudzi } \\
\text { reports, } \\
\text { related to } \\
\text { Eskom and } \\
\text { Transnet (x3) }\end{array}$ & $\begin{array}{l}\text { Final reports } \\
\text { compiled in } \\
\text { November } 2018 \\
\text { and released to } \\
\text { the public shortly } \\
\text { thereafter. }\end{array}$ & $\begin{array}{l}\text { Investigations requested by National Treasury } \\
\text { of alleged corruption at Transnet and Eskom. } \\
\text { The three reports focused on Eskom (general), } \\
\text { the contracts related to Trillian/McKinsey and } \\
\text { Transnet Locomotives. }\end{array}$ & $\begin{array}{l}\text { - National } \\
\text { Treasury } \\
\text { Fundudzi }\end{array}$ & $\begin{array}{l}\text { - Eskom } \\
\text { - Transnet }\end{array}$ \\
\hline \multirow[t]{2}{*}{$\begin{array}{l}\text { Transnet } \\
\text { Locomotive } \\
\text { Contracts }\end{array}$} & \multirow[t]{2}{*}{$\begin{array}{l}\text { Investigations } \\
\text { commenced in } \\
\text { December } 2017 \\
\text { and reports on } \\
\text { findings submitted } \\
\text { during } 2018 .\end{array}$} & $\begin{array}{l}\text { Werksmans Attorneys was appointed in } \\
\text { December } 2017 \text { to undertake an investigation } \\
\text { into the } 1064 \text { Transnet Locomotives } \\
\text { procurement process, however, the investigation } \\
\text { was halted. No report in the public domain. }\end{array}$ & - Werksmans & - Transnet \\
\hline & & $\begin{array}{l}\text { Mncedisi Ndlovu \& Sedumedi (MNS) Attorneys } \\
\text { was then appointed to investigate } 1064 \\
\text { locomotives procurement process. The report } \\
\text { is not in the public domain, but media indicates } \\
\text { that recommendations mirror the Werksmans' } \\
\text { findings and recommends that Molefe face } \\
\text { criminal charges. }\end{array}$ & $\begin{array}{l}\text { - Mncedisi } \\
\text { Ndlovu \& } \\
\text { Sedumedi }\end{array}$ & - Transnet \\
\hline $\begin{array}{l}\text { Inquiry into } \\
\text { State Capture } \\
\text { at Transnet } \\
\text { and Denel }\end{array}$ & $\begin{array}{l}\text { In June } 2017, \\
\text { Parliament directed } \\
4 \text { committees to } \\
\text { investigate state } \\
\text { capture. Committee } \\
\text { hearings were not } \\
\text { completed. }\end{array}$ & $\begin{array}{l}\text { A detailed information booklet was prepared } \\
\text { in relation to Transnet, however, hearings were } \\
\text { not held before the end of term of Parliament. } \\
\text { Following National elections in 2019, it } \\
\text { was decided that outstanding Inquiries into } \\
\text { state capture be postponed indefinitely until } \\
\text { conclusion of the Zondo Commission. }\end{array}$ & $\begin{array}{l}\text { - Portfolio } \\
\text { Committee } \\
\text { on Public } \\
\text { Enterprises }\end{array}$ & $\begin{array}{l}\text { - Transnet } \\
\text { - Denel }\end{array}$ \\
\hline
\end{tabular}




\begin{tabular}{|c|c|c|c|c|}
\hline $\begin{array}{l}\text { Case Study } \\
\text { in State } \\
\text { Capture }\end{array}$ & Status & Summary Description & $\begin{array}{l}\text { Investigation } \\
\text { Body / } \\
\text { Source of } \\
\text { Evidence }\end{array}$ & $\begin{array}{l}\text { Government } \\
\text { Entity } \\
\text { Implicated }\end{array}$ \\
\hline \multicolumn{5}{|c|}{ Scandals Connected to Jacob Zuma, Guptas, Other Key Networks and ANC Politics } \\
\hline \multicolumn{5}{|c|}{ Law Enforcement and the Security Cluster } \\
\hline $\begin{array}{l}\text { Enquiry into } \\
\text { Jiba and } \\
\text { Mrwebi's } \\
\text { fitness to } \\
\text { hold office } \\
\text { at NPA }\end{array}$ & $\begin{array}{l}\text { Established in } \\
\text { November } 2018 . \\
\text { Report was issued } \\
\text { in April } 2019 .\end{array}$ & $\begin{array}{l}\text { Presidential Enquiry into the fitness to hold } \\
\text { office of suspended NPA senior advocates } \\
\text { Nomgcobo Jiba and Lawrence Mrwebi. NPA's } \\
\text { deputy head Jiba, and Mrwebi, the head of } \\
\text { the Specialised Commercial Crimes Unit, were } \\
\text { suspended in October } 2018 \text { by President Cyril } \\
\text { Ramaphosa. The Inquiry was headed by retired } \\
\text { Constitutional Court Justice Yvonne Mokgoro. } \\
\text { Jiba and Mrwebi were accused of improper } \\
\text { conduct in their handling of cases involving } \\
\text { former crime intelligence head Richard Mdluli, } \\
\text { as well as former KwaZulu-Natal Hawks boss } \\
\text { Johan Booysen. }\end{array}$ & $\begin{array}{c}\text { - Mokgoro } \\
\text { Enquiry }\end{array}$ & $\begin{array}{l}\text { - } \text { National } \\
\text { Prosecuting } \\
\text { Authority }\end{array}$ \\
\hline $\begin{array}{l}\text { High-Level } \\
\text { Review Panel } \\
\text { on the State } \\
\text { Security } \\
\text { Agency (SSA) }\end{array}$ & $\begin{array}{l}\text { Established in June } \\
2018 \text { and final } \\
\text { report was sent to } \\
\text { the President in } \\
\text { December } 2018 .\end{array}$ & $\begin{array}{l}\text { The High-Level Review Panel into the SSA } \\
\text { was established by President Ramaphosa in } \\
\text { June 2018. The key finding was a serious } \\
\text { politicisation and factionalisation of the } \\
\text { intelligence community over the past decade } \\
\text { or more. This resulted in "an almost complete } \\
\text { disregard for the Constitution, policy, legislation } \\
\text { and other prescripts, and [turned] our civilian } \\
\text { intelligence community into a private resource } \\
\text { to serve the political and personal interests of } \\
\text { particular individuals" (High-Level Review Panel } \\
\text { on the SSA, 2018, p.ii). }\end{array}$ & $\begin{array}{l}\text { - Review } \\
\text { Panel } \\
\text { established } \\
\text { by President } \\
\text { Ramaphosa }\end{array}$ & - SSA \\
\hline $\begin{array}{l}\text { Various court } \\
\text { cases against } \\
\text { persons } \\
\text { within law } \\
\text { enforcement }\end{array}$ & Ongoing. & $\begin{array}{l}\text { Though testimony and evidence have been } \\
\text { presented at the Zondo Commission, it is } \\
\text { understood that no definitive findings will be } \\
\text { made regarding the capture of law enforcement } \\
\text { under the Zuma administration. Since } 2012 \\
\text { onwards, there were several court cases } \\
\text { that were pursued against individuals in law } \\
\text { enforcement, all of which have been either } \\
\text { dismissed or withdrawn. Most noteworthy are } \\
\text { the cases involved, amongst others: Anwa } \\
\text { Dramat and Shadrack Sibiya of the Hawks } \\
\text { (and Robert McBride from Independent Police } \\
\text { Investigative Directorate [IPID]) for allegations } \\
\text { related to the "Zimbabwean rendition" matter; } \\
\text { Johan Booysen for alleged racketeering as part } \\
\text { of "Cato Manor hit squad"; and the various } \\
\text { senior officials accused of being part of the } \\
\text { "rogue" intelligence unit at SARS. Other court } \\
\text { cases that have provided significant evidence } \\
\text { indicating the capture of law enforcement relate } \\
\text { to the irregular appointed allies of the Shadow } \\
\text { State capture network or the irrational removal } \\
\text { of potential opponents holding senior positions } \\
\text { in law enforcement. Example is the irregular } \\
\text { removal of Mxolisi Nxasana as National Director } \\
\text { of Public Prosecutions (NDPP). }\end{array}$ & $\begin{array}{l}\text { - Various } \\
\text { court cases, } \\
\text { proceedings } \\
\text { in Parlia- } \\
\text { ment } \\
\text { - Zondo } \\
\text { Commission }\end{array}$ & $\begin{array}{l}\text { - NPA } \\
\text { - SAPS } \\
\text { - Hawks } \\
\text { - IPID }\end{array}$ \\
\hline
\end{tabular}




\begin{tabular}{|c|c|c|c|c|}
\hline $\begin{array}{l}\text { Case Study } \\
\text { in State } \\
\text { Capture }\end{array}$ & Status & Summary Description & $\begin{array}{l}\text { Investigation } \\
\text { Body / } \\
\text { Source of } \\
\text { Evidence }\end{array}$ & $\begin{array}{l}\text { Government } \\
\text { Entity } \\
\text { Implicated }\end{array}$ \\
\hline \multicolumn{5}{|c|}{ Scandals Connected to Jacob Zuma, Guptas, Other Key Networks and ANC Politics } \\
\hline \multicolumn{5}{|c|}{ Investigations concerning Private Sector } \\
\hline $\begin{array}{l}\text { Budlender } \\
\text { report on } \\
\text { Trillian }\end{array}$ & $\begin{array}{l}\text { Released in } \\
\text { June } 2017 .\end{array}$ & $\begin{array}{l}\text { Trillian Holdings Board appointed Geoff } \\
\text { Budlender SC to undertake investigations into } \\
\text { State Capture allegations at Trillian Capital. } \\
\text { Detailed accounts from whistle-blowers } \\
\text { highlighted how information was withheld by } \\
\text { senior management at Trillian. }\end{array}$ & - Trillion & - Eskom \\
\hline $\begin{array}{l}\text { Collapse of } \\
\text { VBS Mutual } \\
\text { Bank }\end{array}$ & $\begin{array}{l}\text { Investigation } \\
\text { launched in } \\
\text { April } 2018 \text { and } \\
\text { the report was } \\
\text { released in } \\
\text { October } 2018 .\end{array}$ & $\begin{array}{l}\text { Minister of Finance placed VBS under } \\
\text { curatorship with effect from } 11 \text { March 2018. In } \\
\text { April 2018, the Deputy Governor of the South } \\
\text { African Reserve Bank instituted an investigation } \\
\text { into VBS. The outcomes of the investigation } \\
\text { showed blatant fraud and corruption by senior } \\
\text { executives/Board and how they extracted } \\
\text { money from the bank. Municipal funds were } \\
\text { illegally deposited with VBS (senior ANC and } \\
\text { EFF politicians have been implicated). }\end{array}$ & $\begin{array}{l}\text { - SARB } \\
\text { investiga- } \\
\text { tion report } \\
\text { VBS Mutual } \\
\text { Bank - The } \\
\text { Great Bank } \\
\text { Heist }\end{array}$ & $\begin{array}{l}\text { - Several } \\
\text { Provincial and } \\
\text { Municipal } \\
\text { Officials } \\
\text { (Limpopo } \\
\text { Government) } \\
\text { - SOEs } \\
\text { (particularly } \\
\text { PRASA) }\end{array}$ \\
\hline $\begin{array}{l}\text { SA Institute } \\
\text { of Chartered } \\
\text { Accountants' } \\
\text { (SAICA) } \\
\text { investigation } \\
\text { into KPMG }\end{array}$ & $\begin{array}{l}\text { Final report was } \\
\text { handed to SAICA in } \\
\text { December } 2018 .\end{array}$ & $\begin{array}{l}\text { SA Institute of Chartered Accountants (SAICA) } \\
\text { established an Inquiry to investigate state } \\
\text { capture related allegations of misconduct of its } \\
\text { members who worked for KPMG. The Inquiry } \\
\text { chaired by advocate Dumisa Ntsebeza held } \\
\text { public hearings and handed its final report to } \\
\text { SAICA in December 2018. Indications are that } \\
\text { the final report will not be made public until all } \\
\text { investigations and disciplinary hearings have } \\
\text { been finalised. }\end{array}$ & - SAICA & - Guptas \\
\hline Bell Pottinger & $\begin{array}{l}2017 \text { investigation } \\
\text { by PRCA. }\end{array}$ & $\begin{array}{l}\text { In 2016, the Guptas appointed British PR } \\
\text { company, Bell Pottinger, who developed and } \\
\text { promoted a campaign that underpinned the RET } \\
\text { and WMC narratives. In 2017, there was an } \\
\text { independent law firm review by Herbert Smith } \\
\text { Freehills resulting in Bell Pottinger's expulsion } \\
\text { from the Public Relations and Communications } \\
\text { Association (PRCA). }\end{array}$ & $\begin{array}{l}\text { - PRCA } \\
\text { - GuptaLeaks } \\
\text { - Ongoing } \\
\text { research } \\
\text { on disinfor- } \\
\text { mation }\end{array}$ & - Guptas \\
\hline
\end{tabular}

